\title{
Inhibition of Thrombomodulin Surface Expression and Protein C Activation by the Thrombogenic Agent Homocysteine
}

Steven R. Lentz ${ }^{*}$ and J. Evan Sadler**

${ }^{*}$ Howard Hughes Medical Institute, ${ }^{\ddagger}$ Department of Medicine, Division of Hematology-Oncology, Department of Biochemistry and Molecular Biophysics, Washington University School of Medicine, St. Louis, Missouri 63110

\begin{abstract}
Elevated levels of plasma homocysteine are associated with both venous and arterial thrombosis. Homocysteine inhibits the function of thrombomodulin, an anticoagulant glycoprotein on the endothelial surface that serves as a cofactor for the activation of protein $\mathbf{C}$ by thrombin. The effects of homocysteine on thrombomodulin expression and protein $\mathbf{C}$ activation were investigated in cultured human umbilical vein endothelial cells and CV-1(18A) cells that express recombinant human thrombomodulin. Addition of $5 \mathrm{mM}$ homocysteine to endothelial cells produced slight increases in thrombomodulin mRNA and thrombomodulin synthesis without affecting cell viability. In both cell types, thrombomodulin synthesized in the presence of homocysteine remained sensitive to digestion with endoglycosidase $H$ and failed to appear on the cell surface, suggesting impaired transit along the secretory pathway. In a cell-free protein $\mathbf{C}$ activation assay, homocysteine irreversibly inactivated both thrombomodulin and protein $\mathrm{C}$ in a process that required free thiol groups and was inhibited by the oxidizing agents diamide or $\boldsymbol{N}$-ethylmaleimide. By inhibiting both thrombomodulin surface expression and protein $\mathrm{C}$ activation, homocysteine may contribute to the development of thrombosis in patients with cystathionine $\beta$-synthase deficiency. (J. Clin. Invest. 1991. 88:1906-1914.) Key words: endothelium • glycosylation $\bullet$ homocystinuria $\bullet$ redox $\bullet$ thrombosis
\end{abstract}

\section{Introduction}

Thrombomodulin is an endothelial cell surface glycoprotein that promotes activation of the anticoagulant protein $\mathrm{C}$ and inhibits the procoagulant activities of thrombin (1-3). Negative regulation of thrombomodulin expression occurs when cultured endothelial cells are stimulated with endotoxin (4) or inflammatory cytokines such as interleukin-1 (5) and tumor necrosis factor- $\alpha(6-10)$. The resulting decrease in protein $\mathrm{C}$ activation may contribute to the development of thrombosis and disseminated intravascular coagulation in patients with inflammatory disorders (11).

Homocysteinemia caused by homozygous cystathionine $\beta$-synthase deficiency is associated with an increased incidence of vascular thrombosis (12), and heterozygosity for this condi-

Address correspondence to J. Evan Sadler, M.D., Ph.D., Howard Hughes Medical Institute, Washington University School of Medicine, 660 South Euclid Ave., Box 8045, St. Louis, MO 63110.

Received for publication 12 March 1991 and in revised form 19 June 1991.

J. Clin. Invest.

(c) The American Society for Clinical Investigation, Inc.

0021-9738/91/12/1914/09 \$2.00

Volume 88, December 1991, 1906-1914 tion has been reported to be an independent risk factor for premature arterial occlusive disease (13-16). The mechanisms by which elevated concentrations of plasma homocysteine may lead to thrombosis or atherosclerosis are unknown. Homocysteine has been reported to produce endothelial cell injury when administered intravenously to baboons (17), or when added directly to cultured endothelial cells $(18,19)$. Enhanced Factor $\mathrm{V}$ activity was observed after incubation of human or bovine endothelial cells with homocysteine (20). Recently, the binding of lipoprotein(a) to plasmin-modified fibrin was reported to be increased by homocysteine (21). The effect of homocysteine on thrombomodulin activity was examined by Rodgers and Conn (22), who observed reduced protein $\mathrm{C}$ activation after incubation of cultured endothelial cells with homocysteine, and suggested that homocysteine may compete with thrombin for binding to thrombomodulin.

In this study, the mechanisms by which homocysteine decreases protein $C$ activation were examined in human umbilical vein endothelial cells (HUVEC) ${ }^{1}$ and also in CV-1(18A) monkey kidney cells that express recombinant human thrombomodulin (23). The results suggest that unlike tumor necrosis factor- $\alpha(7,10)$, homocysteine does not decrease thrombomodulin synthesis. Instead, homocysteine inhibits cell-surface thrombomodulin expression and irreversibly inactivates both thrombomodulin and protein $\mathrm{C}$ in a sulfhydryl-dependent process.

\section{Methods}

Materials. DME and fetal bovine serum (FBS) were from Gibco Laboratories (Grand Island, NY), and endothelial cell growth medium was from Clonetics Corp. (San Diego, CA). All radionuclides were from Amersham Corp. (Arlington Heights, IL). Peptide: $N$-glycosidase F ( $N$ glycanase) and endo- $\beta$ - $N$-acetylglucosaminidase (endoglycosidase $H$ ) were from Genzyme Corporation (Cambridge, MA), $N$-ethylmaleimide (NEM) and diazenedicarboxylic acid bis-dimethylamide (diamide) were from Calbiochem Corp. (La Jolla, CA), chondroitinase $\mathrm{ABC}$ was from Boehringer Mannheim Corp. (Indianapolis, IN), and SDS was from Bethesda Research Laboratories (Gaithersburg, MD). DL-homocysteine, DL-cysteine, DL-homocystine, DL-cystine, 2-mercaptoethanol, 1,10-phenanthroline, Nonidet P-40, L-1-p-tosylamino2-phenylethyl chloromethylketone-(TPCK-) treated trypsin, soybean trypsin inhibitor, chondroitin sulfate $\mathrm{C}$, and Tris were from Sigma Chemical Co. (St. Louis, MO). Stock solutions of homocysteine, cysteine, 2-mercaptoethanol, NEM, and diamide were prepared immediately before use in $137 \mathrm{mM} \mathrm{NaCl}, 3 \mathrm{mM} \mathrm{KCl}, 15 \mathrm{mM} \mathrm{Na}_{2} \mathrm{HPO}_{4}, 1.5$ mM KH $\mathrm{PO}_{4}, \mathrm{pH} 7.2$ (PBS). Homocystine and cystine were dissolved in $0.1 \mathrm{~N} \mathrm{HCl}$ before dilution in PBS and adjustment to $\mathrm{pH} 7.2$ with 0.1 $\mathrm{N} \mathrm{NaOH}$.

Cell culture. HUVEC were purchased from Clonetics Corp. and cultured between passages 2 and 8 in endothelial cell growth medium

1. Abbreviations used in this paper: HUVEC, human umbilical vein endothelial cells; NEM, N-ethylmaleimide. 
(MCDB 131, $10 \mathrm{ng} / \mathrm{ml}$ epidermal growth factor, $0.4 \%$ bovine brain extract, $10 \mu \mathrm{g} / \mathrm{ml}$ heparin, $1 \mu \mathrm{g} / \mathrm{ml}$ hydrocortisone, $2 \% \mathrm{FBS}, 50 \mu \mathrm{g} / \mathrm{ml}$ gentamicin, and $0.5 \mu \mathrm{g} / \mathrm{ml}$ amphotericin-B). CV-1(18A) monkey kidney cells expressing recombinant human thrombomodulin (23) were cultured in DME, $10 \% \mathrm{FBS}, 100 \mathrm{U} / \mathrm{ml}$ penicillin, and $100 \mu \mathrm{g} / \mathrm{ml}$ streptomycin.

Nuclease S1 protection analysis. HUVEC were incubated with 5 $\mathrm{mM}$ homocysteine for the indicated times, and total cellular RNA was isolated by the method of Chomczynski and Sacchi (24). End-labeled probes specific for human thrombomodulin (from plasmid pUC19TM12 [10]) and human $\gamma$ actin (from plasmid pHF $\gamma$ A-1, provided by Dr. L. Kedes, University of Southern California, Pasadena [25]) were prepared as described previously (10), and hybridized overnight at $55^{\circ} \mathrm{C}$ with 20 or $5 \mu \mathrm{g}$ of HUVEC RNA, respectively. Hybridization conditions, nuclease S1 digestion, and analysis on denaturing PAGE were as described previously $(10,26)$. Protected fragments of 243 and 325 nucleotides were detected for thrombomodulin and actin, respectively.

Metabolic labeling of cellular proteins. Confluent monolayers of HUVEC $\left(\sim 0.5 \times 10^{6}\right.$ cells/well $)$ were labeled in $1.0 \mathrm{ml}$ cysteine-free or leucine-free medium containing dialyzed FBS. CV-1(18A) cells were labeled in cysteine-free medium without serum. For measurement of thrombomodulin synthesis, HUVEC were preincubated with $5 \mathrm{mM}$ homocysteine for $0-22 \mathrm{~h}$, washed three times with the appropriate labeling medium, and incubated for $2 \mathrm{~h}$ in $1.0 \mathrm{ml}$ labeling medium containing $5 \mathrm{mM}$ homocysteine and $100 \mu \mathrm{Ci}\left[{ }^{35} \mathrm{~S}\right]$ cysteine or $\left[{ }^{3} \mathrm{H}\right]$ leucine. Control cells were labeled for $\mathbf{2} \mathrm{h}$ without homocysteine. For continuous labeling experiments, cells were incubated with $100 \mu \mathrm{Ci}\left[{ }^{35} S\right]$ cysteine in $1.0 \mathrm{ml}$ labeling medium containing either $5 \mathrm{mM}$ homocysteine or PBS. For sulfate labeling experiments, CV-1(18A) cells $\left(3 \times 10^{6}\right.$ cells/well) were incubated for $24 \mathrm{~h}$ in $3.0 \mathrm{ml}$ sulfate-free medium containing 300 $\mu \mathrm{Ci}\left[{ }^{35} \mathrm{~S}\right]$ sulfate.

For determination of cell-surface thrombomodulin, labeled cells were washed with serum-free medium, and digested with $300 \mu \mathrm{l}$ of 0.1 $\mathrm{mg} / \mathrm{ml} \mathrm{TPCK}$-treated trypsin for $60 \mathrm{~min}$ at $23^{\circ} \mathrm{C}$. Trypsin digestion was terminated by the addition of $150 \mu \mathrm{l}$ of $10 \mathrm{mg} / \mathrm{ml}$ soybean trypsin inhibitor. Control cells were treated with soybean trypsin inhibitor prior to addition of TPCK-treated trypsin.

Thrombomodulin immunoprecipitation and gel electrophoresis. After metabolic labeling, cells were washed with PBS, and cell lysates were prepared as described previously (23). Thrombomodulin was immunoprecipitated with a rabbit polyclonal antiserum raised against a synthetic peptide corresponding to the carboxyl terminal sequence of human thrombomodulin (10). Immunoprecipitated thrombomodulin was collected on protein A Sepharose as described previously (23), and analyzed by SDS-PAGE under reducing conditions with $10 \%$ polyacryl- amide separating gels (27), followed by autoradiography and fluorography (28).

Glycosidase digestions. Metabolically labeled thrombomodulin was immunoprecipitated, and eluted from protein A Sepharose by incubation at $95^{\circ} \mathrm{C}$ for $5 \mathrm{~min}$ in $0.5 \%$ SDS. Digestion with $25 \mathrm{U} / \mathrm{ml}$ $N$-glycanase was performed in $0.2 \mathrm{M}$ tris-chloride, $\mathrm{pH} 8.0,0.17 \%$ (wt/ vol) SDS, 1.25\% (vol/vol) Nonidet P-40, $33 \mathrm{mM}$ 2-mercaptoethanol, and $10 \mathrm{mM}$ 1,10-phenanthroline. Digestion with $0.1 \mathrm{U} / \mathrm{ml}$ endoglycosidase $H$ was performed in $50 \mathrm{mM}$ sodium phosphate, $\mathrm{pH} 5.5,0.17 \%$ (wt/vol) SDS, and $33 \mathrm{mM} 2$-mercaptoethanol. Digestion with $0.3 \mathrm{U} / \mathrm{ml}$ chondroitinase $\mathrm{ABC}$ was performed in $40 \mathrm{mM}$ tris-chloride, $40 \mathrm{mM}$ sodium acetate, $\mathrm{pH} 8.0,1.33 \%$ (vol/vol) Nonidet P-40, and $0.17 \%$ (wt/ vol) SDS. All digestions were incubated at $37^{\circ} \mathrm{C}$ for $24 \mathrm{~h}$, and analyzed by SDS-PAGE. Control digestion of chondroitin sulfate $\mathrm{C}$ by chondroitinase $\mathrm{ABC}$ was assayed by the method of Reissig et al. (29).

Densitometry. Autoradiographic signals were quantitated with an UltraScan XL laser densitometer (Pharmacia LKB Biotechnology Inc., Piscataway, NJ).

Protein $C$ activation. Human thrombin was prepared as described previously (23). Protein $C$ was purified from pooled human plasma by barium absorption and immunoaffinity chromatography with monoclonal antibody hC-2 (provided by Dr. J. Miletich, Washington University, St. Louis, MO) as described previously (30). Human antithrombin III was provided by Dr. Douglas Tollefsen (Washington University, St. Louis, MO). CV-1(18A) cell lysate was used as the source of thrombomodulin in cell-free protein $C$ activation assays. These cells, which express $\sim 220,000$ molecules of thrombomodulin per cell (23), were lysed in assay buffer ( $50 \mathrm{mM}$ Tris-chloride, $\mathrm{pH} 8.0,2 \mathrm{mM} \mathrm{CaCl}_{2}, 100$ $\mathrm{mM} \mathrm{NaCl}, 0.1 \%$ bovine albumin, $0.6 \%$ (vol/vol) Triton X-100), and nuclei were removed by centrifugation. Thrombomodulin-dependent protein $C$ activation was measured in assay buffer containing $13 \mathrm{nM}$ thrombin, $0.8 \mu \mathrm{M}$ protein $\mathrm{C}, 0.16 \mathrm{nM}$ thrombomodulin, and various concentrations of homocysteine. Thrombomodulin-independent protein $\mathrm{C}$ activation was measured either in assay buffer or calcium-free assay buffer containing $5 \mathrm{mM}$ EDTA. Reactions were incubated for 30 min at $37^{\circ} \mathrm{C}$, antithrombin III and heparin were added to inhibit residual thrombin activity, and activated protein $\mathrm{C}$ was determined by hydrolysis of the chromogenic substrate S-2366 as described previously (10). For concentration curves, an exponential decay function $(y$ $=A e^{-B x}$ ) was fitted to the data using the RS/1 system (BBN Software Products Corp., Cambridge, MA), and $\mathrm{IC}_{50}$ was defined as the concentration of homocysteine that resulted in $50 \%$ inhibition of protein $\mathrm{C}$ activation.

For preincubation experiments, thrombin, CV-1(18A) thrombomodulin, or protein $C$ were incubated in assay buffer for $60 \mathrm{~min}$ at $37^{\circ} \mathrm{C}$ with the indicated concentrations of sulfhydryl agents. Following
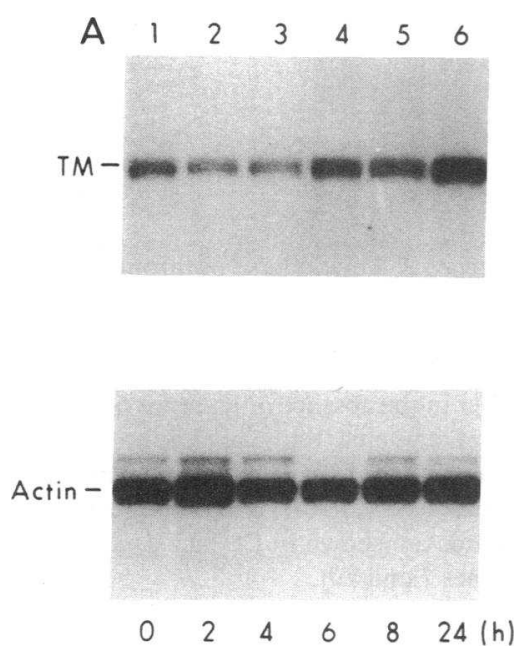

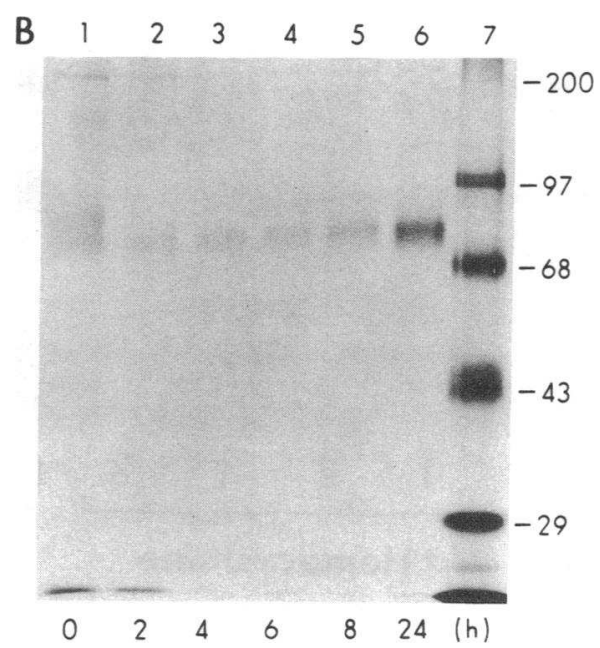

Figure 1. Effect of homocysteine on thrombomodulin mRNA level and protein synthesis. $(A)$ At the indicated times after addition of $5 \mathrm{mM}$ homocysteine, total cellular RNA was isolated from HUVEC, hybridized with thrombomodulin or actin probes, and analyzed by nuclease S1 protection. (B) HUVEC were incubated for the indicated times with $5 \mathrm{mM}$ homocysteine (lanes 2-6); ${ }^{35}$ S]cysteine was added for the final $2 \mathrm{~h}$ of the incubation. Radiolabeled thrombomodulin was immunoprecipitated and analyzed by SDS-PAGE. Control cells were labeled with $\left[{ }^{35} \mathrm{~S}\right]$ cysteine for $2 \mathrm{~h}$ without homocysteine (lane 1 ). The mass of protein standards (lane 7) is indicated in kilodaltons. 
preincubation, samples were diluted 25 -fold with assay buffer, and protein $\mathrm{C}$ activation was performed for $30 \mathrm{~min}$ at $37^{\circ} \mathrm{C}$. In control experiments without preincubation, protein $\mathrm{C}$ activation was unaffected by direct addition of diluted sulfhydryl agents.

\section{Results}

In previous studies, endothelial cell cytotoxicity has been reported to occur in proportion to the concentrations of both homocysteine and serum in the culture medium $(18,19)$. The medium used in the present study contained $2 \%$ fetal bovine serum, and concentrations of homocysteine from 0.01 to 5 $\mathrm{mM}$ did not produce cell detachment or significant loss of HUVEC viability ( $<10 \%$ trypan blue positivity). Increased cell lysis $(\sim 40 \%)$ was observed after incubation with $10 \mathrm{mM}$ homocysteine for $24 \mathrm{~h}$. In the presence of 1-5 mM homocysteine, the cells adopted an elongated shape similar to that seen after stimulation with tumor necrosis factor (31).
Effect of homocysteine on thrombomodulin synthesis. To determine whether homocysteine affected thrombomodulin mRNA expression, total cellular RNA was isolated from HUVEC at various times after addition of $5 \mathrm{mM}$ homocysteine, and thrombomodulin or actin mRNAs were assayed by nuclease $\mathrm{S} 1$ protection (Fig. $1 \mathrm{~A}$ ). Quantitative densitometry showed that thrombomodulin mRNA, normalized to actin mRNA, increased by two- to fourfold after $24 \mathrm{~h}$ of incubation with homocysteine (Fig. $1 A$, lane 6 ). The slight decrease in thrombomodulin mRNA observed $2-4 \mathrm{~h}$ after addition of homocysteine in Fig. $1 A$ (lanes 2 and 3) was not reproducibly observed in other experiments.

Similar results were obtained when thrombomodulin synthesis was examined by pulse labeling HUVEC for $2 \mathrm{~h}$ with $\left[{ }^{35}\right.$ S]cysteine (Fig. $1 B$ ). Incubation with $5 \mathrm{mM}$ homocysteine resulted in a $10-30 \%$ decrease in incorporation of $\left[{ }^{35} \mathrm{~S}\right]$ cysteine into total TCA precipitable protein during the 2-h labeling pe-

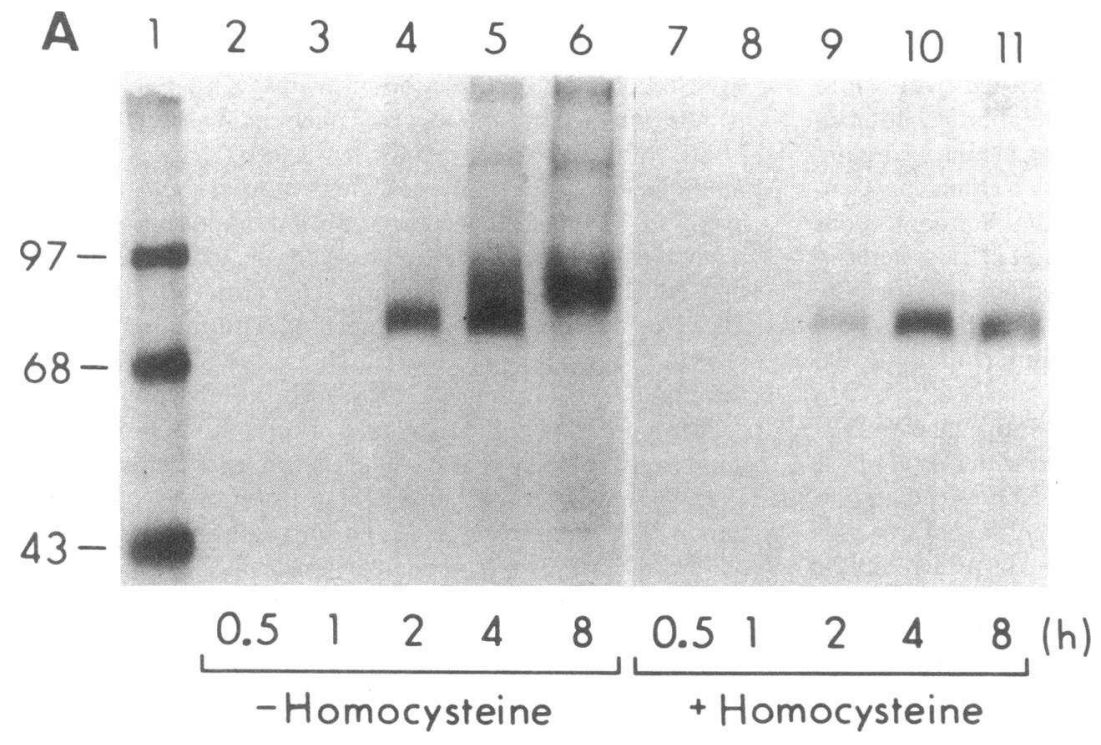

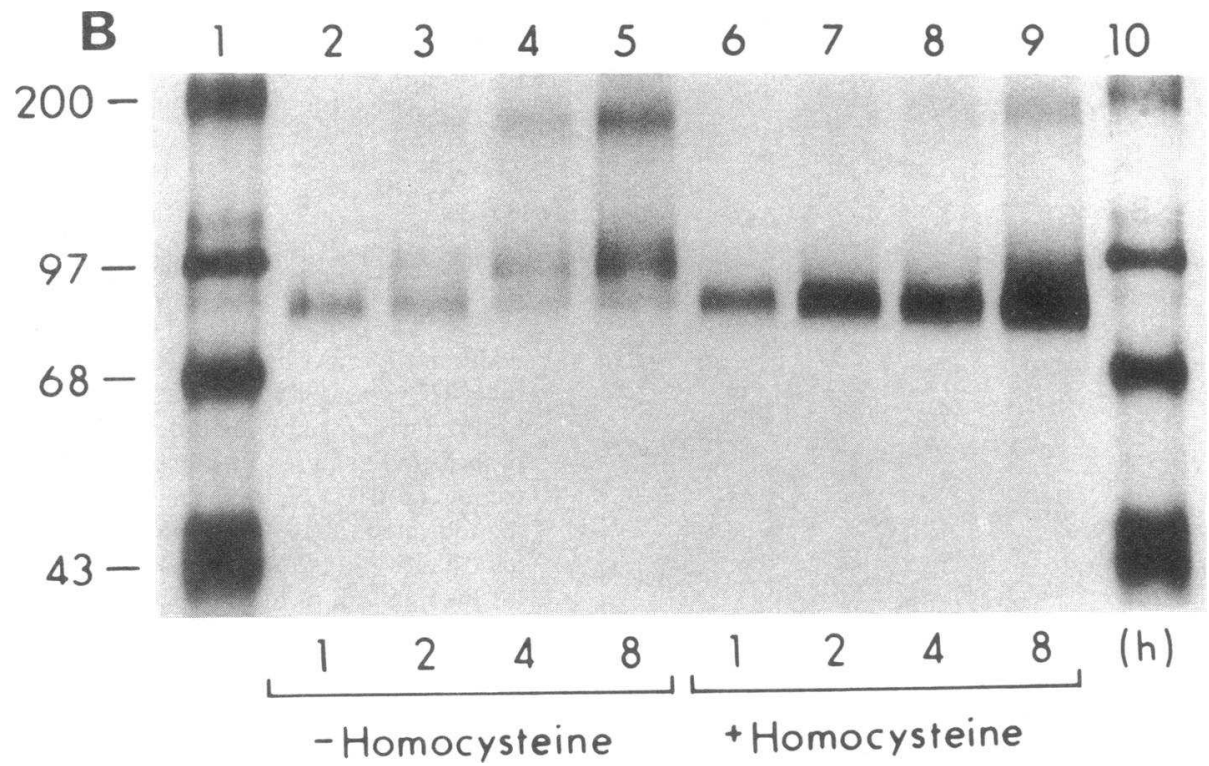

Figure 2. Time course of thrombomodulin synthesis. HUVEC $(A)$ or CV$1(18 \mathrm{~A})$ cells $(B)$ were incubated with $\left.{ }^{35} \mathrm{~S}\right]$ cysteine for the indicated times either in the absence or presence of $5 \mathrm{mM}$ homocysteine. Radiolabeled thrombomodulin was immunoprecipitated and analyzed by SDS-PAGE. Protein standards are shown in $(A$, lane 1$)$ and $(B$, lanes 1 and 10). 
riod, possibly due to the formation of $\left[{ }^{35}\right.$ S $]$ cysteinehomocysteine-mixed disulfides (32). In spite of this generalized inhibitory effect on metabolic labeling, an approximately twofold increase in $\left[{ }^{35} \mathrm{~S}\right]$ thrombomodulin synthesis was observed $24 \mathrm{~h}$ after addition of homocysteine (Fig. $1 \mathrm{~B}$, lane 6 ). Homocysteine also produced an approximately twofold increase in thrombomodulin synthesis when HUVEC were labeled with $\left[{ }^{3} \mathrm{H}\right]$ leucine, without affecting metabolic labeling of total protein (data not shown). These results suggest that decreased protein $\mathrm{C}$ activation after homocysteine treatment does not result from decreased thrombomodulin synthesis.

Effect of homocysteine on thrombomodulin glycosylation. Human thrombomodulin contains complex-type asparaginelinked oligosaccharide chains, and may contain additional serine/threonine-linked carbohydrates (2). Chondroitin sulfate glycosaminoglycan chains have been identified on rabbit thrombomodulin (33) and secretable recombinant human thrombomodulin $(34,35)$. The possibility that homocysteine may affect thrombomodulin glycosylation was suggested by the differences in appearance on SDS-PAGE of radiolabeled thrombomodulin from homocysteine-treated and untreated cells (Fig. $1 B$, lanes 1 and 6 ). To examine this possibility, the time course of thrombomodulin glycosylation in HUVEC was followed during an 8-h incubation with $\left[{ }^{35} \mathrm{~S}\right]$ cysteine. After labeling for up to $2 \mathrm{~h}$ without homocysteine, an 80,000-D band was immunoprecipitated (Fig. $2 A$, lane 4). After longer labeling times, a 95,000-D band corresponding to mature thrombomodulin became the predominant product (Fig. $2 \mathrm{~A}$, lanes 5 and 6). In the presence of $5 \mathrm{mM}$ homocysteine however, the 80,000 -D band remained the major product after $8 \mathrm{~h}$ (Fig. $2 \mathrm{~A}$, lanes 9-11). In separate experiments with homocysteine, no mature 95,000-D thrombomodulin was observed after labeling for up to $24 \mathrm{~h}$, and no immunoprecipitable thrombomodulin was detectable in the culture medium.

Thrombomodulin glycosylation was examined further in CV-1(18A) cells that express recombinant human thrombomodulin (23). The effect of homocysteine on the time course of thrombomodulin labeling in these cells was similar to that in HUVEC (Fig. 2 B). As previously observed (23), the apparent molecular weight on SDS-PAGE of CV-1(18A) thrombomodulin was $\sim 5,000$ D larger than HUVEC thrombomodulin. A nonspecific band migrating near the top of the gel was variably observed after long labeling times with both immune and nonimmune serum. The asparagine-linked oligosaccharide struc-

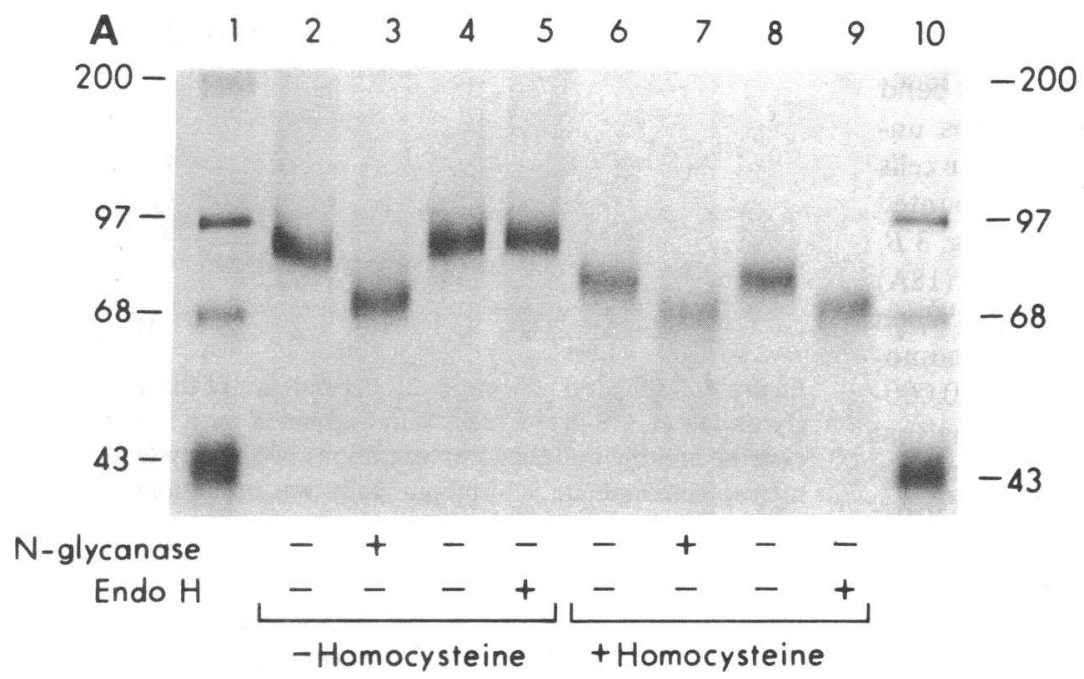

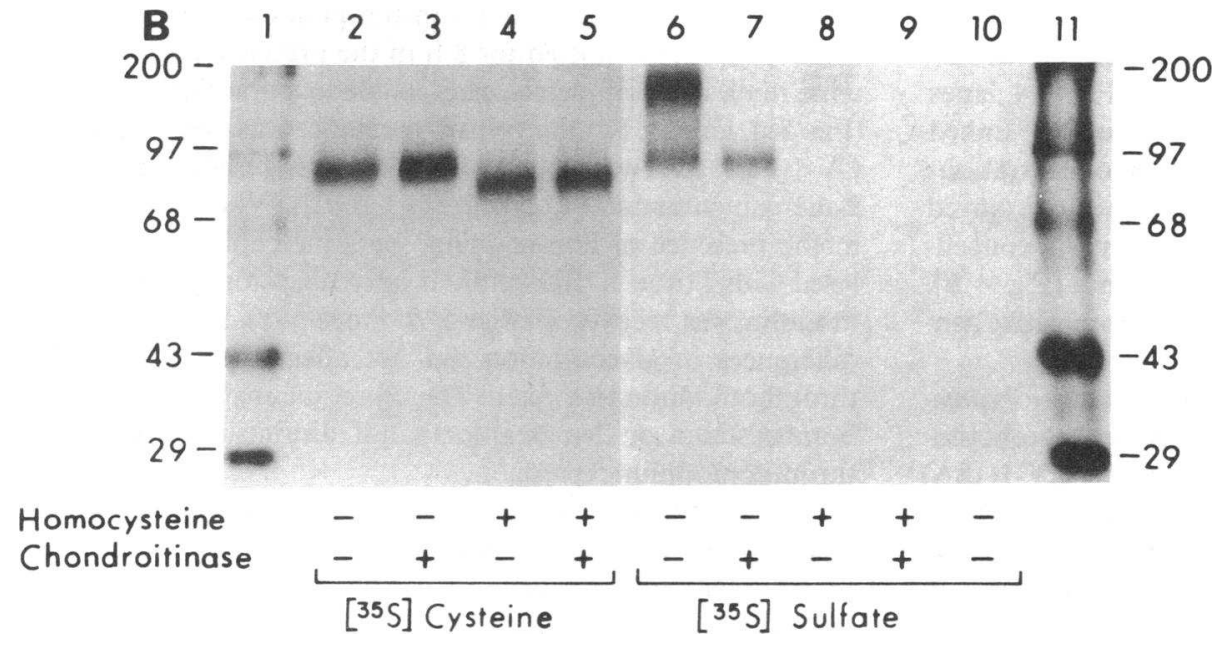

Figure 3. Glycosidase digestion of thrombomodulin. $(A) \mathrm{CV}-1$ (18A) cells were incubated for $6 \mathrm{~h}$ with $\left[{ }^{35} \mathrm{~S}\right]$ cysteine either in the absence or presence of 5 $\mathrm{mM}$ homocysteine. Radiolabeled thrombomodulin was immunoprecipitated, and incubated with $N$-glycanase or endoglycosidase $H$ (Endo $H$ ) as indicated (lanes 3, 5, 7, 9). Control samples were incubated under identical conditions without glycosidases (lanes 2, 4, 6, 8 ). Protein standards are shown in lanes $l$ and 10 . (B) CV-1(18A) cells were incubated for $24 \mathrm{~h}$ with $\left[^{35} \mathrm{~S}\right]$ cysteine (lanes $2-5$ ) or ${ }^{35}$ S] sulfate (lanes $6-10$ ), either in the absence or presence of 5 $\mathrm{mM}$ homocysteine. Radiolabeled thrombomodulin was immunoprecipitated and incubated either with or without chondroitinase $\mathrm{ABC}$ as indicated. In lane 10 , immunoprecipitation was performed with nonimmune rabbit serum. Protein standards are shown in lanes $l$ and 11 . The slightly increased mobility of undigested thrombomodulin in this figure compared to Fig. 2 is due to different salt and detergent concentrations of the samples. 
tures of recombinant thrombomodulin were evaluated by digestion with $N$-glycanase or endoglycosidase $H$. The mobility of radiolabeled thrombomodulin synthesized in the absence of homocysteine increased after digestion with $N$-glycanase (Fig. $3 A$, lane 3 ), but was unaffected by digestion with endoglycosidase $H$ (Fig. $3 A$, lane 5), demonstrating that complex-type asparagine-linked oligosaccharides were present. In contrast, thrombomodulin synthesized in the presence of homocysteine migrated with increased electrophoretic mobility after digestion with either $N$-glycanase or endoglycosidase $H$ (Fig. $3 \mathrm{~A}$, lanes 7 and 9), consistent with the presence of high-mannose oligosaccharide chains (36). These findings suggest that the increased electrophoretic mobility of thrombomodulin synthesized in the presence of homocysteine resulted from impaired processing of asparagine-linked oligosaccharides.

Attachment of a chondroitin sulfate glycosaminoglycan to recombinant soluble human thrombomodulin has been shown to increase the catalytic efficiency of protein $C$ activation (34). To determine if CV-1(18A) thrombomodulin contained chondroitin sulfate, cells were labeled with either $\left[{ }^{35} \mathrm{~S}\right]$ cysteine or $\left[{ }^{35} \mathrm{~S}\right]$ sulfate, and radiolabeled thrombomodulin was digested with chondroitinase $\mathrm{ABC}$. When cells were labeled with $\left[{ }^{35} \mathrm{~S}\right]-$ sulfate in the absence of homocysteine, a major 160,000-D band was immunoprecipitated in addition to mature 100,000D thrombomodulin (Fig. $3 \mathrm{~B}$, lane 6). This 160,000-D band was not immunoprecipitated by nonimmune serum (Fig. $3 B$, lane 10). After chondroitinase digestion, the 160,000-D band was no longer observed, but the $100,000-\mathrm{D}$ band was unchanged in mobility and intensity (Fig. $3 \mathrm{~B}$, lane 7 ). When cells were labeled with $\left[{ }^{35}\right.$ S $]$ cysteine, the 160,000 -D band accounted for $<10 \%$ of immunoprecipitated thrombomodulin (Fig. $3 B$, lane 2), suggesting that only a small fraction of CV-1(18A) thrombomodulin is associated with chondroitin sulfate. When cells were incubated with $\left[{ }^{35} \mathrm{~S}\right]$ sulfate in the presence of homocysteine, decreased labeling of both the 160,000 - and 100,000$\mathrm{D}$ bands occurred (Fig. $3 \mathrm{~B}$, lanes 8 and 9), suggesting that homocysteine inhibits the incorporation of sulfate into both chondroitinase-sensitive and chondroitinase-resistant structures.

Thrombomodulin oligosaccharide processing was examined further as a function of homocysteine concentration. With homocysteine concentrations $<1.0 \mathrm{mM}$, mature thrombomodulin was the major product immunoprecipitated from ${ }^{35}$ S]cysteine-labeled cells (Fig. $4 A$, lanes 1 and 2 ). When the homocysteine concentration was increased, a progressive decrease in mature thrombomodulin and increase in incompletely glycosylated thrombomodulin occurred (Fig. $4 \mathrm{~A}$, lanes 3-6). Complete inhibition of complex-type asparagine-linked glycosylation was observed with homocysteine concentrations $\geq 5 \mathrm{mM}$. Increased mobility of thrombomodulin also occurred when CV-1(18A) cells were incubated with millimolar concentrations of the sulfhydryl agent 2-mercaptoethanol (Fig. $4 \mathrm{~B}$ ), suggesting that oligosaccharide processing may be sensitive generally to thiol reducing agents.

Effect of homocysteine on thrombomodulin surface expression. The effect of homocysteine on cell-surface thrombomodulin expression was evaluated by digesting intact CV-1(18A) cells with trypsin. As demonstrated by resistance to exogenous trypsin, thrombomodulin remained intracellular after labeling for $1 \mathrm{~h}$ either with or without $5 \mathrm{mM}$ homocysteine (Fig. $5 \mathrm{~A}$, lanes 3 and 7). After labeling for $8 \mathrm{~h}$ in the absence of homocys-
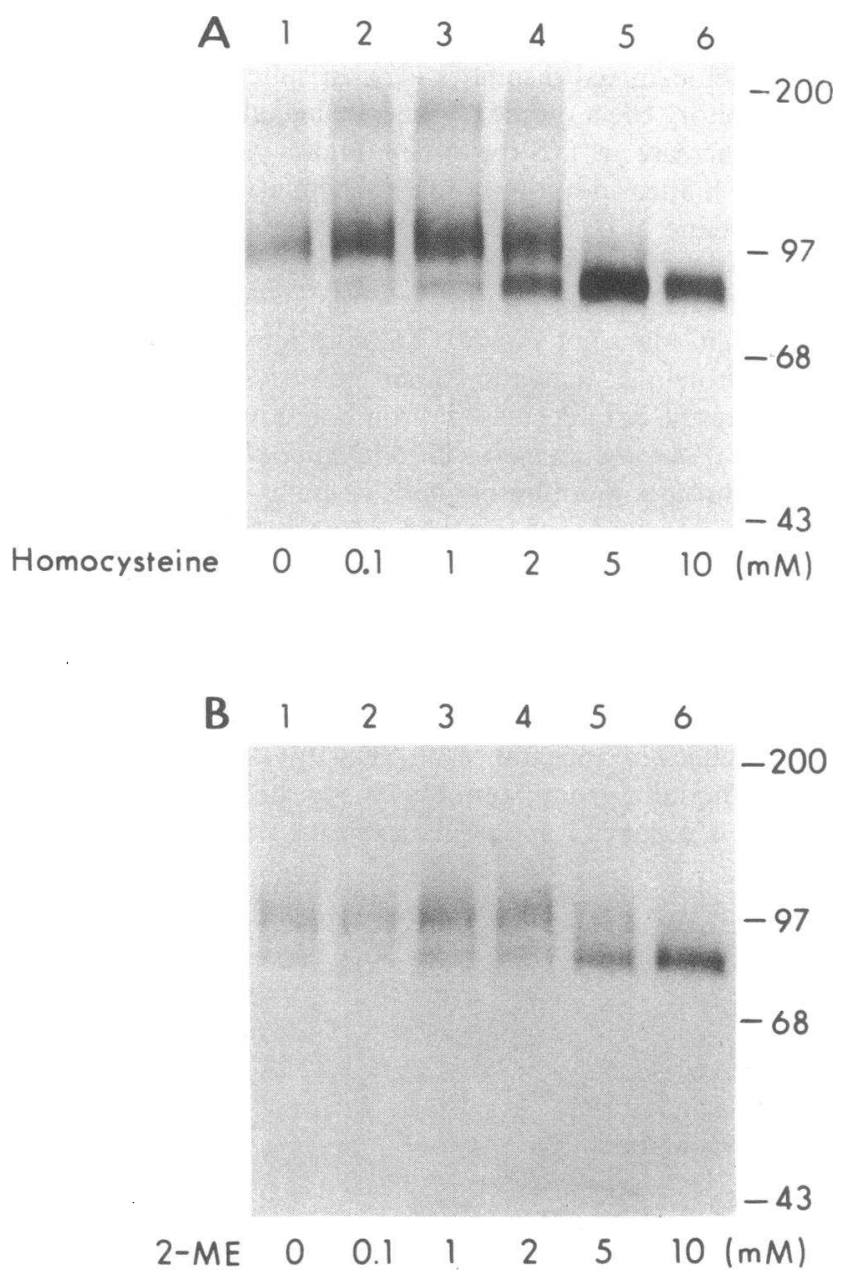

Figure 4. Sulfhydryl concentration dependence of thrombomodulin glycosylation. CV-1(18A) cells were incubated for $6 \mathrm{~h}$ with $\left[{ }^{35} \mathrm{~S}\right]-$ cysteine and the indicated concentrations of homocysteine $(A)$ or 2mercaptoethanol $(B)$. Thrombomodulin was immunoprecipitated and analyzed by SDS-PAGE.

teine, mature thrombomodulin was sensitive to trypsin digestion (Fig. $5 \mathrm{~A}$, lanes 4 and 5), consistent with expression on the cell-surface. The minor, partially glycosylated product that remained trypsin-resistant (Fig. $5 A$, lanes 4 and 5) represents newly synthesized intracellular thrombomodulin. In contrast, thrombomodulin labeled for $8 \mathrm{~h}$ in the presence of homocysteine remained completely inaccessible to extracellular trypsin (Fig. $5 A$, lane 9). Similar trypsin resistance was observed when CV-1(18A) cells were labeled for $8 \mathrm{~h}$ in the presence of $10 \mathrm{mM}$ 2-mercaptoethanol (Fig. $5 B$, lanes 4 and 5). When cells labeled in the presence of homocysteine or 2-mercaptoethanol were lysed with Triton X-100 before trypsin digestion, no thrombomodulin was recovered (Fig. $5 B$, lanes $6-8$ ), indicating that differences in glycosylation did not affect the sensitivity of thrombomodulin to trypsin. Therefore, incubation with either homocysteine or 2-mercaptoethanol diminishes cell-surface thrombomodulin expression.

Effect of homocysteine on protein $C$ activation. Direct effects of homocysteine on protein $\mathrm{C}$ activation were measured in vitro with mature thrombomodulin from untreated CV$1(18 \mathrm{~A})$ cells. In the presence of $2-\mathrm{mM}$ calcium ions, the activa- 

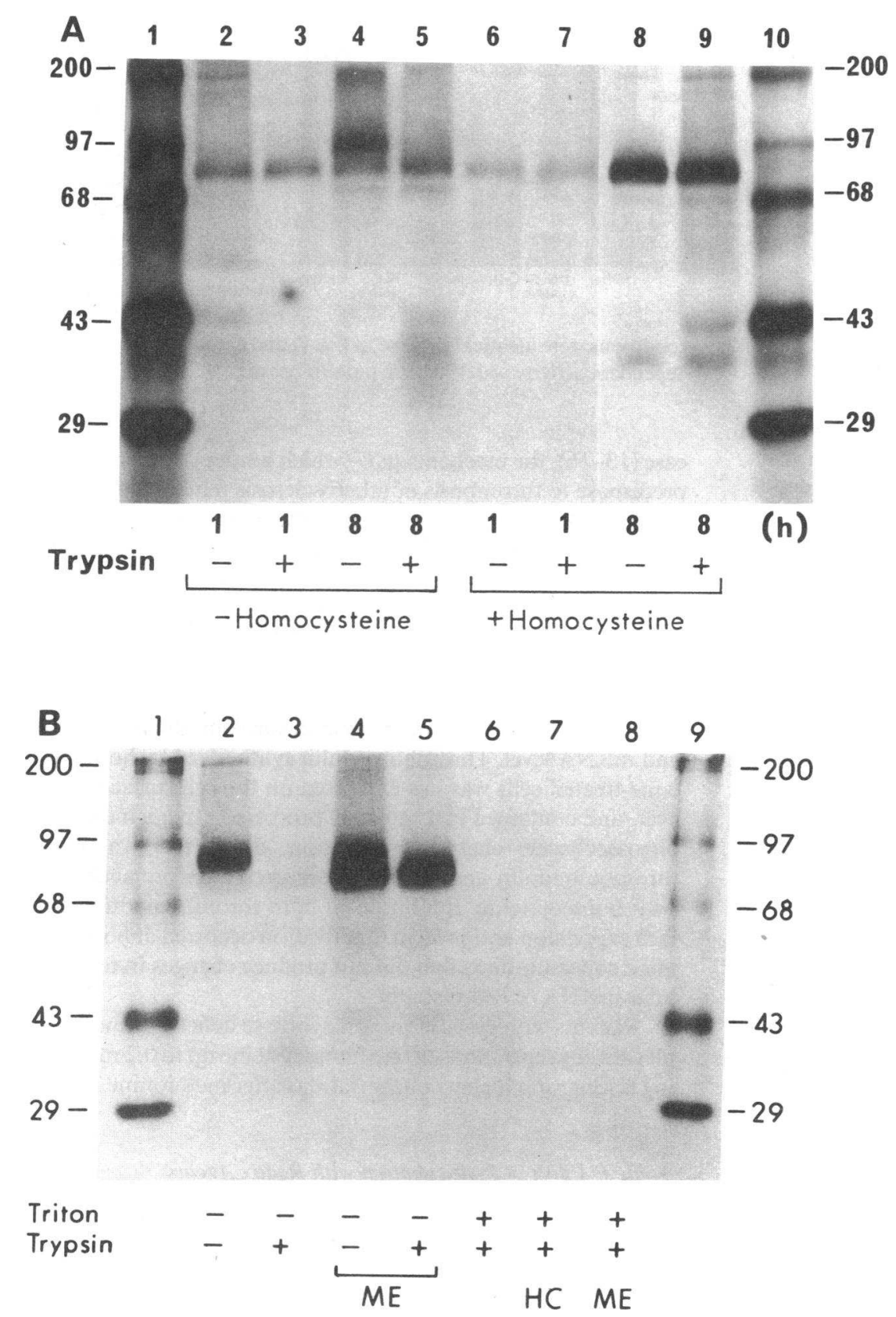

Figure 5. Trypsin digestion of cell-surface thrombomodulin. $(A) \mathrm{CV}-1(18 \mathrm{~A})$ cells were incubated with $\left[{ }^{35} \mathrm{~S}\right]$ cysteine for 1 or $8 \mathrm{~h}$, either in the absence or presence of $5 \mathrm{mM}$ homocysteine. After labeling, intact cells were incubated with trypsin for $60 \mathrm{~min}$, excess trypsin inhibitor was added, and thrombomodulin was immunoprecipitated and analyzed by SDS-PAGE (lanes 3, 5, 7, 9). Control cells were treated with trypsin inhibitor before addition of trypsin (lanes $2,4,6,8$ ). Protein standards are shown in lanes 1 and 10 . (B) CV-1(18A) cells were incubated with $\left[{ }^{35} \mathrm{~S}\right]$ cysteine for $8 \mathrm{~h}$ either in the absence (lanes 2 and 3) or presence (lanes 4 and 5) of $10 \mathrm{mM} 2$-mercaptoethanol, and digested with trypsin as in $(A)$. For lanes $6-8$, cells incubated in the presence of buffer (lane 6), $5 \mathrm{mM}$ homocysteine (lane 7), or $10 \mathrm{mM}$ 2-mercaptoethanol (lane 8 ) were lysed in $0.6 \%$ Triton X-100 before trypsin digestion. Protein standards are shown in lanes 1 and 9 .

tion of protein $\mathrm{C}$ by thrombin was accelerated $\sim 20$-fold by $0.16 \mathrm{nM}$ thrombomodulin (Fig. $6 \mathrm{~A}$ ). Addition of homocysteine inhibited thrombomodulin-dependent protein $\mathrm{C}$ activation in a concentration-dependent manner, with $\mathrm{IC}_{50}$ $=2.2 \pm 0.3 \mathrm{mM}$ (SD). High concentrations of homocysteine also appeared to inhibit thrombomodulin-independent protein $\mathrm{C}$ activation (Fig. $6 \mathrm{~A}$ ). This effect was confirmed when protein $\mathrm{C}$ activation was measured in the absence of calcium ions, a condition that enhances thrombomodulin-independent activity (1); in this case homocysteine inhibited with $\mathrm{IC}_{50}=1.3 \pm 0.4$ $\mathrm{mM}(\mathrm{SD})$ (Fig. $6 \mathrm{~B}$ ). The similarity of this concentration dependence to that reported after preincubation of endothelial cells with homocysteine (22) suggested that homocysteine may directly inactivate one or more components of the reaction.

To determine which components of the reaction were sen- sitive to homocysteine, thrombin, protein C, and thrombomodulin were individually preincubated with $5 \mathrm{mM}$ homocysteine for $60 \mathrm{~min}$ at $37^{\circ} \mathrm{C}$. After preincubation, the samples were diluted to a final homocysteine concentration of $0.2 \mathrm{mM}$ to prevent further inhibition by homocysteine during the subsequent protein $\mathrm{C}$ activation assay. As shown in Fig. 7, preincubation of protein $\mathrm{C}$ or thrombomodulin with homocysteine decreased protein $C$ activation by $>80 \%$, but preincubation with thrombin had little effect. These results suggest that inactivation of both thrombomodulin and protein $C$ contribute to the decreased protein $\mathrm{C}$ activation observed in the presence of homocysteine.

The specificity of inactivation was examined using additional sulfhydryl agents. Protein $\mathrm{C}$ activation decreased following preincubation of thrombomodulin with $5 \mathrm{mM}$ homocys- 

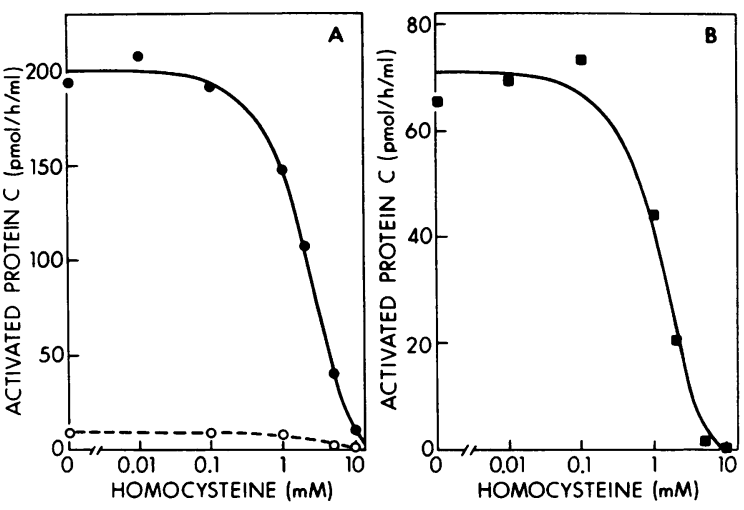

Figure 6. Effect of homocysteine on protein $\mathrm{C}$ activation. $(A)$ Protein $\mathrm{C}$ activation was measured in the presence of $13 \mathrm{nM}$ thrombin, 0.8 $\mu \mathrm{M}$ protein $\mathrm{C}, 2.0 \mathrm{mM} \mathrm{CaCl}_{2}$, and the indicated concentrations of homocysteine. Filled circles, with $0.16 \mathrm{nM}$ thrombomodulin; open circles, without thrombomodulin. (B) Thrombomodulin-independent protein $C$ activation was measured in the presence of $13 \mathrm{nM}$ thrombin, $0.8 \mu \mathrm{M}$ protein $\mathrm{C}, 5 \mathrm{mM}$ EDTA, and the indicated concentrations of homocysteine.

teine, cysteine, or 2-mercaptoethanol, all of which contain free thiol groups (Fig. 8). No inhibition was observed following preincubation with the same concentration of the disulfides homocystine or cystine. Similar results were obtained after preincubation of protein C (data not shown). Further evidence for thiol-dependent inactivation was provided by the addition of the oxidizing agents $N$-ethylmaleimide (NEM) or diamide. Preincubation of thrombomodulin or protein $\mathrm{C}$ with $10 \mathrm{mM}$ NEM or diamide completely prevented inactivation by $5 \mathrm{mM}$ homocysteine (Table I). When thrombomodulin or protein $\mathrm{C}$ was first inactivated with $5 \mathrm{mM}$ homocysteine no recovery of cofactor activity occurred during a subsequent $60 \mathrm{~min}$ incubation with $10 \mathrm{mM}$ NEM or diamide (data not shown). Therefore, homocysteine inactivates both thrombomodulin and protein $\mathrm{C}$ by an irreversible, sulfhydryl-dependent mechanism.

\section{Discussion}

Although cystathionine $\beta$-synthase deficiency has been implicated as an independent risk factor for premature vascular dis-

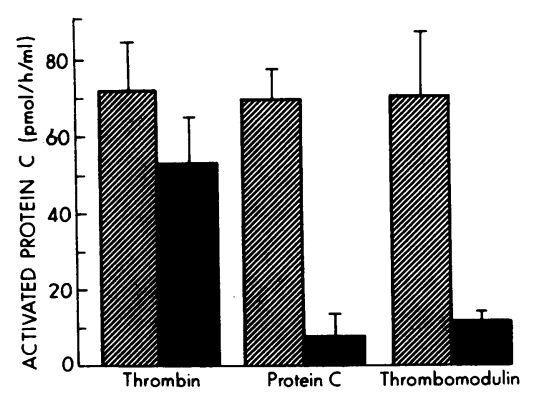

Figure 7. Effect of preincubation with homocysteine on protein C activation. Thrombin, protein $\mathrm{C}$, or thrombomodulin were incubated for $60 \mathrm{~min}$ at $37^{\circ} \mathrm{C}$ with either PBS (hatched bars) or $5 \mathrm{mM}$ homocysteine (solid bars) before measurement of protein $\mathrm{C}$ activation.

Final concentrations during protein $\mathrm{C}$ activation were $13 \mathrm{nM}$ thrombin, $0.8 \mu \mathrm{M}$ protein $\mathrm{C}, 0.06 \mathrm{nM}$ thrombomodulin, $2.0 \mathrm{mM} \mathrm{CaCl}_{2}$, and $0.2 \mathrm{mM}$ homocysteine. Values represent mean $\pm \mathrm{SD}$ of triplicate determinations. In this experiment thrombomodulin-independent activity was $14.5 \pm 2.9 \mathrm{pmol} / \mathrm{h}$ per ml.

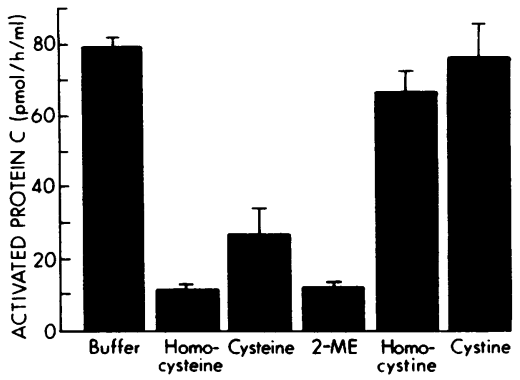

Figure 8. Specificity of thrombomodulin inactivation by sulfhydryl agents. Protein $\mathrm{C}$ activation (mean \pm SD of triplicate determinations) was measured following preincubation of thrombomodulin with $5 \mathrm{mM}$ concentrations of the indicated sulfhydryl agents. Assay conditions were identical to those in Fig. 7, and thrombomodulin-independent activity was $10.4 \pm 0.2 \mathrm{pmol} / \mathrm{h}$ per $\mathrm{ml}$.

ease (13-16), the mechanisms by which homocysteinemia may predispose to thrombosis or atherosclerosis remain largely unknown. This study suggests that homocysteine may compromise the anticoagulant potential of vascular endothelial cells indirectly by decreasing cell-surface thrombomodulin expression, and directly by inhibiting protein $\mathrm{C}$ activation. Unlike tumor necrosis factor- $\alpha$, which inhibits protein $\mathrm{C}$ activation primarily by decreasing thrombomodulin gene transcription $(7,10)$, incubation of HUVEC with homocysteine produced slight (two- to fourfold) increases in thrombomodulin synthesis and mRNA level. Thrombomodulin synthesized by homocysteine-treated cells was not expressed on the cell surface, however, and contained incompletely processed asparagine-linked oligosaccharide chains. In addition, direct inactivation of thrombomodulin and protein $\mathrm{C}$ occurred after preincubation with homocysteine. Inhibition of both thrombomodulin surface expression and protein $\mathrm{C}$ activation occurred at homocysteine concentrations that did not produce changes in total cellular mRNA or cell viability.

Patients with cystathionine $\beta$-synthase deficiency may have plasma concentrations of free homocysteine up to $0.2 \mathrm{mM}$ during fasting, and higher concentrations after methionine loading

Table I. Effect of Preincubation with Redox Agents on Protein C Activation

\begin{tabular}{|c|c|c|}
\hline \multirow[b]{2}{*}{ Agent } & \multicolumn{2}{|c|}{ Activated Protein $\mathrm{C}^{*}$} \\
\hline & $\begin{array}{l}\text { Thrombomodulin } \\
\text { preincubation }\end{array}$ & $\begin{array}{c}\text { Protein C } \\
\text { preincubation }\end{array}$ \\
\hline & \multicolumn{2}{|c|}{$\mathrm{pmol} / \mathrm{h}$ per $\mathrm{ml}$} \\
\hline Buffer & $65.4 \pm 2.9$ & $78.1 \pm 12.4$ \\
\hline Homocysteine & $16.1 \pm 3.7$ & $2.4 \pm 0.3$ \\
\hline NEM & $65.5 \pm 3.2$ & $70.8 \pm 2.8$ \\
\hline Diamide & $64.8 \pm 4.2$ & $74.8 \pm 9.9$ \\
\hline NEM \pm homocysteine & $68.1 \pm 1.1$ & $70.7 \pm 2.1$ \\
\hline Diamide + homocysteine & $66.4 \pm 11.1$ & $74.4 \pm 0.8$ \\
\hline
\end{tabular}

* Thrombomodulin and protein $\mathrm{C}$ were preincubated for $60 \mathrm{~min}$ at $37^{\circ} \mathrm{C}$ with PBS, $5 \mathrm{mM}$ homocysteine, $10 \mathrm{mM}$ NEM, and/or $10 \mathrm{mM}$ diamide before measurement of protein $\mathrm{C}$ activation. Final concentrations during protein $C$ activation were $0.8 \mu \mathrm{M}$ protein $\mathrm{C}, 13 \mathrm{nM}$ thrombin, $0.06 \mathrm{nM}$ thrombomodulin, and $2 \mathrm{mM} \mathrm{CaCl}_{2}$. Values are expressed as the mean $\pm \mathrm{SD}$ of triplicate determinations. Thrombomodulin-independent activity was $11.7 \pm 1.4 \mathrm{pmol} / \mathrm{h}$ per $\mathrm{ml}$. 
(32). Plasma homocysteine exists largely in mixed disulfide and protein-bound forms, so that total plasma homocysteine appears to reach millimolar concentrations in many patients (37). Effects on thrombomodulin and protein $\mathrm{C}$ in such patients may vary depending on differences in local concentrations of free homocysteine, the duration of homocysteinemia, and other factors affecting redox potential.

Both thrombomodulin and protein $\mathrm{C}$ contain disulfide-rich epidermal growth factor domains. Reduction of these disulfide bonds by homocysteine or other reducing agents may disrupt important structures within these domains, resulting in impaired function. In contrast to previous findings (22), our data are not consistent with simple competitive inhibition of thrombin binding, because $(a)$ inhibition of protein $\mathrm{C}$ activation occurred both in the presence and absence of thrombomodulin, and $(b)$ inactivation of thrombomodulin and protein $\mathrm{C}$ by homocysteine was irreversible.

Thrombomodulin synthesized in the presence of homocysteine retained high-mannose asparagine-linked oligosaccharide chains, resulting in decreased apparent molecular weight on SDS-PAGE. Unlike thrombomodulin from control cells, this abnormally glycosylated thrombomodulin remained inaccessible to extracellular trypsin, suggesting that transport to the cell surface was inhibited. General disruption of the secretory pathway did not occur, because secretion of plasminogen activator inhibitor type 1 was unaffected by homocysteine (data not shown). Terminal processing of asparagine-linked oligosaccharides occurs late in the secretory pathway, in the Golgi complex (36). Therefore, homocysteine or 2-mercaptoethanol may inhibit transport of thrombomodulin from the endoplasmic reticulum to the Golgi complex. Retention of secretory or plasma membrane proteins in the endoplasmic reticulum is a selective process that results in some cases from abnormal folding of newly synthesized polypeptides (38). Because it contains a large number of intrachain disulfide bonds, thrombomodulin may be particularly sensitive to denaturation by sulfhydryl reducing agents such as homocysteine or 2-mercaptoethanol.

Inhibition of thrombomodulin glycosylation by homocysteine may contribute to decreased protein $\mathrm{C}$ activation. Although asparagine-linked oligosaccharides do not appear to be necessary for thrombin binding (39), glycosaminoglycan attachment has been shown to affect both protein $\mathrm{C}$ activation (34) and the direct anticoagulant activities of thrombomodulin (33-35). Glycosaminoglycan association with CV-1(18A) thrombomodulin appears to be inefficient, because the chondroitinase-sensitive 160,000 -D band represented $<10 \%$ of total $\left[{ }^{35} S\right]$ cysteine-labeled thrombomodulin (Fig. 3 B). Decreased incorporation of $\left[{ }^{35} \mathrm{~S}\right]$ sulfate into the chondroitinase-sensitive band in the presence of homocysteine is consistent with disruption of intracellular transit, because sulfate addition to chondroitin sulfate occurs late in the secretory pathway (40). Homocysteine also decreased $\left[{ }^{35} \mathrm{~S}\right]$ sulfate labeling of chondroitinaseresistant thrombomodulin, suggesting that the sulfation of amino acids or other carbohydrates may also be inhibited. However, because thrombomodulin synthesized in the presence of homocysteine was not expressed on the cell surface, alteration of carbohydrate or amino acid sulfate should not affect extracellular protein $\mathrm{C}$ activation.

Changes in the concentration of extracellular sulfhydryl reducing agents can modulate important intracellular functions of many kinds. Addition of 2-mercaptoethanol to myeloma cells altered both intracellular transport and secretion of $\mathrm{I}_{8} \mathrm{M}$ and free $J$ chains (41). Oxidation-reduction mechanisms have been shown to be important in cytoplasmic processes, including regulation of ferritin translation (42), fos-jun DNA binding (43), and NF- $\kappa B$ activation (43). The results presented here suggest that cell-surface thrombomodulin expression is inhibited by alteration of the extracellular redox potential. Both decreased thrombomodulin cell-surface expression and direct inhibition of protein $C$ activation may contribute to the increased risk of vascular disease in patients with homocysteinemia.

\section{Acknowledgements}

This work was supported in part by research grants from the Specialized Center of Research in Thrombosis (HLBI 14147) and from the National Institutes of Health (T32 HLBI 07088). Steven R. Lentz is a W. M. Keck Fellow.

\section{REFERENCES}

1. Esmon, N. L., W. G. Owen, and C. T. Esmon. 1982. Isolation of a membrane-bound cofactor for thrombin-catalyzed activation of protein C. J. Biol. Chem. 257:859-864.

2. Dittman, W. A., and P. W. Majerus. 1990. Structure and function of thrombomodulin: a natural anticoagulant. Blood. 75:329-336.

3. Esmon, C. T. 1989. The roles of protein $C$ and thrombomodulin in the regulation of blood coagulation. J. Biol. Chem. 264:4743-4746.

4. Moore, K. L., S. P. Andreoli, N. L. Esmon, C. T. Esmon, and N. U. Bang. 1987. Endotoxin enhances tissue factor and suppresses thrombomodulin expression of human vascular endothelium in vitro. J. Clin. Invest. 79:124-130.

5. Nawroth, P. P., D. A. Handley, C. T. Esmon, and D. M. Stern. 1986. Interleukin 1 induces endothelial cell procoagulant while suppressing cell-surface anticoagulant activity. Proc. Natl. Acad. Sci. USA. 83:3460-3464.

6. Nawroth, P. P., and D. M. Stern. 1986. Modulation of endothelial cell hemostatic properties by tumor necrosis factor. J. Exp. Med. 163:740-745.

7. Conway, E. M., and R.D. Rosenberg. 1988. Tumor necrosis factor suppresses transcription of the thrombomodulin gene in endothelial cells. $\mathrm{Mol}$. Cell. Biol. 8:5588-5592.

8. Moore, K. L., C. T. Esmon, and N. L. Esmon. 1989. Tumor necrosis factor leads to the internalization and degradation of thrombomodulin from the surface of bovine aortic endothelial cells in culture. Blood. 73:159-165.

9. Scarpati, E. M., and J. E. Sadler. 1989. Regulation of endothelial cell coagulant properties. Modulation of tissue factor, plasminogen activator inhibitors, and thrombomodulin by phorbol 12-myristate 13-acetate and tumor necrosis factor. J. Biol. Chem. 264:20705-20713.

10. Lentz, S. R., M. Tsiang and J. E. Sadler. 1991. Regulation of thrombomodulin by tumor necrosis factor- $\alpha$ : comparison of transcriptional and posttranscriptional mechanisms. Blood. 77:542-550.

11. Esmon, C. T. 1987. The regulation of natural anticoagulant pathways. Science (Wash. DC). 235:1348-1352.

12. Mudd, S. H., F. Skovby, H. L. Levy, K. D. Pettigrew, B. Wilcken, R. E. Pyeritz, G. Andria, G. H. J. Boers, I. L. Bromberg, R. Cerone, B. Fowler, H. Gröbe, H. Schmidt, and L. Schweitzer. 1985. The natural history of homocystinuria due to cystathionine $\beta$-synthase deficiency. Am. J. Hum. Genet. 37:1-31.

13. Boers, G. H. J., A. G. H. Smals, F. J. M. Trijbels, B. Fowler, J. A. J. M. Bakkeren, H. C. Schoonderwaldt, W. J. Kleijer, and P. W. C. Kloppenborg. 1985. Heterozygosity for homocystinuria in premature peripheral and cerebral occlusive arterial disease. N. Engl. J. Med. 313:709-715.

14. Israelsson, B., L. E. Brattström, and B. L. Hultberg. 1988. Homocysteine and myocardial infarction. Atherosclerosis. 71:227-233.

15. Malinow, M. R., S. S. Kang, L. M. Taylor, P. W. K. Wong, B. Coull, T. Inahara, D. Mukerjee, G. Sexton, and B. Upson. 1989. Prevalence of hyperhomocystinemia in patients with peripheral arterial occlusive disease. Circulation. 79:1180-1188.

16. Clarke, R., L. Daly, K. Robinson, E. Haughten, S. Cahalane, B. Fowler, and I. Graham. 1991. Hyperhomocysteinemia: an independent risk factor for vascular disease. $N$. Engl. J. Med. 324:1149-1155.

17. Harker, L. A., S. J. Slichter, C. R. Scott, and R. Ross. 1974. Homocystinemia. Vascular injury and arterial thrombosis. N. Engl. J. Med. 291:537-543.

18. Wall, R. T., J. M. Harlan, L. A. Harker, and G. E. Striker. 1980. Homocysteine-induced endothelial cell injury in vitro: a model for the study of vascular injury. Thromb. Res. 18:113-121. 
19. Starkebaum, G., and J. M. Harlan. 1986. Endothelial cell injury due to copper-catalyzed hydrogen peroxide generation from homocysteine. J. Clin. Invest. 77:1370-1376.

20. Rodgers, G. M., and W. H. Kane. 1986. Activation of endogenous factor $\mathrm{V}$ by a homocysteine-induced vascular endothelial cell activator. J. Clin. Invest. 77:1909-1916.

21. Harpel, P. C., V. T. Chang, and W. Borth. 1990. Homocysteine enhances the binding of lipoprotein(a) to plasmin-modified fibrin providing a potential link between thrombosis and atherogenesis. Blood. 76:510a.

22. Rodgers, G. M., and M. T. Conn. 1990 . Homocysteine, an atherogenic stimulus, reduces protein $\mathrm{C}$ activation by arterial and venous endothelial cells. Blood. 75:895-901.

23. Tsiang, M., S. R. Lentz, W. A. Dittman, D. Wen, E. M. Scarpati, and J. E Sadler. 1990. Equilibrium binding of thrombin to recombinant human thrombomodulin: effect of hirudin, fibrinogen, factor $\mathrm{Va}$, and peptide analogues. Biochemistry 29:10602-10612.

24. Chomczynski, P., and N. Sacchi. 1987. Single-step method of RNA isolation by acid guanidinium thiocyanate-phenol-chloroform extraction. Anal. Bio chem. 162:156-159.

25. Gunning, P., P. Ponte, H. Okayama, J. Engle, H. Blau, and L. Kedes 1983. Isolation and characterization of full-length $\mathrm{CDNA}$ clones for human $\alpha-, \beta-$ and $\gamma$-actin mRNAs: skeletal but not cytoplasmic actins have an amino-terminal cysteine that is subsequently removed. Mol. Cell Biol. 3:787-795.

26. Dittman, W. A., T. Kumada, J. E. Sadler, and P. W. Majerus. 1988. The structure and function of mouse thrombomodulin. Phorbol myristate acetat stimulates degradation and synthesis of thrombomodulin without affecting mRNA levels in hemangioma cells. J. Biol. Chem. 263:15815-15822.

27. Laemmli, U. K. 1970. Cleavage of structural proteins during the assembly of the head of bacteriophage T4. Nature (Lond.). 227:680-685.

28. Bonner, W. M., and R. A. Laskey. 1974. A film detection method for tritium-labelled proteins and nucleic acids. Eur. J. Biochem. 46:83-88.

29. Reissig, J. L., J. L. Strominger, and L. F. Leloir. 1956. A modified method for the estimation of N-acetylamino sugars. J. Biol. Chem. 217:959-966.

30. Miletich, J. P., and G. J. Broze. 1990. $\beta$ Protein C is not glycosylated at asparagine 329. The rate of translation may influence the frequency of usage at asparagine-X-cysteine sites. J. Biol. Chem. 265:11397-11404.

31. Sato, N., T. Goto, K. Haranaka, N. Satomi, H. Nariuchi, Y. ManoHirano, and Y. Sawasaki. 1986. Actions of tumor necrosis factor on cultured vascular endothelial cells: morphologic modulation, growth inhibition, and cytotoxicity. J. Natl. Cancer Inst. 76:1113-1121.

32. Mudd, S. H., H. L. Levy, and F. Skovby. 1989. Disorders of transsulfura- tion. In The Metabolic Basis of Inherited Disease. 6th ed. C. R. Scriver, A. L Beaudet, W. S. Sly, and D. Valle, editors. McGraw-Hill Inc., New York. 693-734.

33. Bourin, M.-C., E Lundgren-Äkerlund, and U. Lindahl. 1990. Isolation and characterization of the glycosaminoglycan component of rabbit thrombomodulin proteoglycan. J. Biol. Chem. 265:15424-15431.

34. Parkinson, J. F., B. W. Grinnell, R. E. Moore, J. Hoskins, C. J. Vlahos, and N. U. Bang. 1990. Stable expression of a secretable deletion mutant of recombinant human thrombomodulin in mammalian cells. J. Biol. Chem. 265:1260212610.

35. Nawa, K., K. Sakano, H. Fujiwara, Y. Sato, N. Sugiyama, T. Teruuchi, M. Iwamoto, and Y. Marumoto. 1990. Presence and function of chondroitin-4-sulfate on recombinant human soluble thrombomodulin. Biochem. Biophys. Res. Commun. 171:729-737.

36. Kornfeld, R., and S. Kornfeld. 1985. Assembly of asparagine-linked oligosaccharides. Annu. Rev. Biochem. 54:631-664.

37. Olszewski, A. J., and W. B. Szostak 1988. Homocysteine content of plasma proteins in ischemic heart disease. Atherosclerosis. 69:109-113.

38. Lodish, H. F. 1988. Transport of secretory and membrane glycoproteins from the rough endoplasmic reticulum to the golgi. A rate-limiting step in protein maturation and secretion. J. Biol. Chem. 263:2107-2110.

39. Stearns, D. J., S. Kurosawa, and C. T. Esmon. 1989. Microthrombomodulin. Residues 310-486 from the epidermal growth factor precursor homology domain of thrombomodulin will accelerate protein C activation. J. Biol. Chem. 264:3352-3356.

40. Sugumaran, G., and J. E. Silbert. 1991. Subfractionation of chick embryo epiphyseal cartilage golgi. Localization of enzymes involved in the synthesis of the polysaccharide portion of proteochondroitin sulfate. J. Biol. Chem. 266:9565-9569.

41. Alberini, C. M., P. Bet, C. Milstein, and R. Sitia. 1990. Secretion of immunoglobulin $\mathbf{M}$ assembly intermediates in the presence of reducing agents. Nature (Lond.). 347:485-487.

42. Hentze, M. W., T. A. Rouault, J. B. Harford, and R. D. Klausner. 1989. Oxidation-reduction and the molecular mechanism of a regulatory RNA-protein interaction. Science (Wash. DC). 244:357-359.

43. Abate, C., L. Patel, F. J. Rauscher, and T. Curran. 1990. Redox regulation of fos and jun DNA-binding activity in vitro. Science (Wash. DC). 249:11571161 .

44. Staal, F. J. T., M. Roederer, L. A. Herzenberg, and L. A. Herzenberg. 1990. Intracellular thiols regulate activation of nuclear factor $\mathrm{\kappa B}$ and transcription of human immunodeficiency virus. Proc. Natl. Acad. Sci. USA. 87:99439947. 